\title{
Comparison between barley malt protein quantification methods
}

\author{
Isabella de Oliveira CENCI ${ }^{1}$, Bernardo Pontes GUIMARÃES ${ }^{1}$, Renato Fernando AMABILE², \\ Grace Ferreira GHESTI ${ }^{1 \star}$
}

\begin{abstract}
Brazil imports about $60 \%$ of all the malt used by the brewing industry which is spread throughout the country. Even though it is an agricultural country, only a small portion of the barley production has the characteristics to produce barley malt for brewing. Seeking supply to the ever-growing demand and reducing the dependency on other countries and logistic costs, malting industries and genetic enhancement companies endeavor to adapt barley to the Brazilian Savannah conditions. For the barley to be malted, it is crucial to develop cultivars with the necessary malting qualities and adapted to the region and with good yield. Considering the importance of protein to the brewing process, four protein quantification methods were compared: combustion methods - carbon, hydrogen and nitrogen elemental analysis and Dumas - and digestion ones - Kjeldahl and flux injection analysis (FIA). The methodologies tested showed good correlations (higher than 0.881 ) and variations were associated with matrix complexity. All protein quantification methods were satisfactory from an agronomic perspective. Yet, we recommend the combustion ones as they generate fewer residues and results are ready in up to 6 minutes. Therefore, they are the most suited for barley and malt analysis considering lab routine.
\end{abstract}

Keywords: protein quantification; barley protein; Kjeldahl; Dumas.

Practical Application: Use of different methodologies to quantify barley and its malt faster and with fewer residues.

\section{Introduction}

On average, Brazil consumes up to 60.7 liters of beer per capita. Since 2007, Brazil is the third largest beer producer and consumer of the world (Dias \& Falconi, 2018). In its production, barley malt is the most used input and Brazilian normative states that up to $45 \%$ of primitive extract may be substituted by adjuncts. For barley to be suited for malting must have specific characteristics, such as grain size, husk, starch, and protein contents. It is known that the higher the protein content, the lower the starch (Fox, 2008). Therefore, Brazilian law states that barley to be considered appropriate for brewing use must have up to $12 \%$ protein content (Brasil, 1996).

High protein content in malting barley slows down the malting process and negatively impacts beer qualities. Grains with such characteristic are usually harder as protein binds together the starch granules to the endosperm's cell wall, causing them to be tighter (Brennan et al., 1996). This hardness causes a worse water and enzyme distribution throughout the endosperm, slowing its modification and degradation, consequently, slowing down the malting process (Psota et al., 2007; Piacentini, 2015). Besides, for beer brewing the high protein content promotes high viscosity and turbidity, reducing shelf-life and also process yield (Molina-Cano et al.,1997; Zhang et al., 2001; Sá \& Palmer, 2004; Fox, 2008; Scobie \& Jones, 2010; Jamar et al., 2011; Fang et al., 2019). Thus, precisely measure barley's protein content and then malt's is crucial to avoid economic losses.

The official methodologies used for protein quantification in food are Kjeldahl and Dumas (Jung et al., 2003; Chang \&
Zhang, 2017). Both are based on nitrogen quantification in samples. The Dumas method or nitrogen combustion method was created in 1831 and avoids the use of corrosive chemical products; but it does not only quantify protein, it also considers inorganic nitrogen including nitrate, nitrite, and some other organic ones, as nucleic acids. This causes the protein content to be overestimated (Jung et al., 2003; Garcia et al., 2015; Krausová et al.,2018). The Kjeldahl method was created in 1833 and meant for the brewing industry, as it can be used to measure the differences in protein content in grains throughout the malting and fermentation processes (Kjeldahl, 1883; Sáez-Plaza et al., 2013a). Using this methodology is susceptible to mistakes as it requires several steps, is time-consuming and generates health hazardous residues, causing environment pollution (Buckee, 1994; Jung et al., 2003; Sáez-Plaza et al., 2013a; Garcia et al., 2015).

Alternatively, some authors suggest the adaption of these classic methodologies. Garcia et al. (2015) used an elemental analyzer to determine the Carbon, Hydrogen, Nitrogen (CHN), and even Sulfur content simultaneously, it works by burning the samples in a similar manner to Dumas. Other researchers claim that flux injection analysis (FIA) is an excellent tool to automate Kjeldahl methodology (Watson \& Galliher, 2001; Sáez-Plaza et al., 2013b).

Thereby, the purpose of this paper is to compare Kjeldahl and Dumas methods to barley cultivated in several places. The procedures used were both the classic methods and their adaptation (FIA and CHN elemental analysis).

${ }^{1}$ Laboratório de Bioprocessos Cervejeiros e Catálise em Energias Renováveis, Instituto de Química, Universidade de Brasília - UNB, Campus Darcy Ribeiro, Brasília, DF, Brasil ${ }^{2}$ Empresa Brasileira de Pesquisa Agropecuária - Embrapa Cerrados, Planaltina, DF, Brasil

*Corresponding author: ghesti.grace@gmail.com 


\section{Materials and methods}

Four two-row barley samples of two different genotypes were grown in 2016 and 2017. The genotype BRS Brau was cultivated in the Midwestern part of Brazil, both in the Federal District (CFI) and in the State of Goiás (CFN); the other, BRS Cauê, was grown in the Federal District (CFE) and in the Southern part of Brazil (CP) and donated by Fundação Agrária de Pesquisa Agropecuária (FAPA) located in Guarapuava, Paraná, Brazil. 50 g of each sample was milled and homogenized for further analysis.

\subsection{Combustion methods}

For the combustion methods, $0.2000 \mathrm{~g}$ of sample was used for Dumas (EBC 4.3.2) and 0.0020 $\mathrm{g}$ for CHN elemental analysis at $925^{\circ} \mathrm{C}$. In both methods, the sample preparation was done during the process by combustion. The gases released were then analyzed by gas chromatography equipped with a thermic conductor detector.

\subsection{Digestion methods}

The digestion methods analyzed were Kjeldahl and flux injection analysis (FIA). Digestion was the same for both methods and it used $0.2000 \mathrm{~g}$ of sample, $2 \mathrm{~mL}$ of concentrated sulfuric acid and $0.2000 \mathrm{~g}$ of Kjeldahl catalyst. All reactants were obtained from Sigma-Aldrich. Kjeldahl was conducted as is and FIA was conducted according to QuikChem ${ }^{\circledR}$ Method 13-107-06-2-G (Sáez-Plaza et al., 2013b).

\subsection{Statistical analysis}

In order to analyze and validate the results, we calculated the standard deviation (s), variation coefficient (VC\%) and confidence interval (CI) between replicates for each analysis. We analyzed the data variance and grouped the averages by the Scott-Knott test (5\% significance) with the aid of Genes program (Cruz, 2013). The variance analysis was done individually for each method using the randomized block design.

\section{Results and discussion}

Most of the barley was cultivated in the Brazilian Savannah has more than $12 \%$ protein content, which makes it unsuitable for malting by law (Brasil, 1996). The CP sample was used as standard malting barley as it was cultivated in the Southern part of Brazil and it is a commercial crop. It was the only one with adequate protein content for commercialization, between $9.19 \%$ and $10.65 \%$. The other crops obtained between $12.31 \%$ (CFE) and $17.43 \%$ (CFI), depending on the crop or quantification method used, as shown in Table 1.

Table 1 highlights the difference between the values obtained for each method. FIA, Kjeldahl and Dumas had similar averages, up to $2.22 \%$, statistically equal to the uncertainty of the method and Scott-Knott test (5\% significance). The three methodologies did not create a second group by Scott-Knott for CP, but for other samples Kjeldahl created a second group.

The CFI sample obtained a different group by Scott-Knott for the $\mathrm{CHN}$ result (15.70\%), it was lower than FIA and Dumas (16.58\% and $17.43 \%$, respectively) and was the one with the highest variation coefficient (8.17\%). In all cases, $\mathrm{CHN}$ had the highest VC, suggesting imprecision of the measurement. This is due to different particle size, sampling or weight variation in each measurement. Barley has an extremely heterogeneous composition, even varying from grain to grain, making sampling and particle size determinant for precise results (Briggs, 1998; Smith \& Tabatabai, 2003; Rutherford et al., 2008).

Nevertheless, for digestion analysis, a high precision was achieved as the standard deviations were low (0.06-0.31). On the other hand, higher deviations for CHN were obtained. This variation was not attributed to sample preparation errors, since the procedure was performed for all methodologies by using a Jones-type quarter and, subsequently, the samples were milled for greater homogenization. The size of particles used for carrying out the procedures was taken into account, which may require specifications not covered in the operational procedures.

Kjeldahl, FIA and Dumas require approximately $0.2000 \mathrm{~g}$ of sample, whereas CHN uses only $0.0020 \mathrm{~g}$. This reduction is a

Table 1. Protein content quantification by Kjeldahl, flux injection analysis (FIA), Carbon, Hydrogen and Nitrogen (CHN) elemental analysis and Dumas and their standard deviation and variation coefficient. Letters identify Scott-Knot groups. The samples are CP for BRS Cauê commercial crop cultivated in Southern Brazil; CFE for BRS Cauê in the Federal District; CFI for BRS Brau in the Federal District; and CFN for BRS Brau in State of Goiás, Brazil.

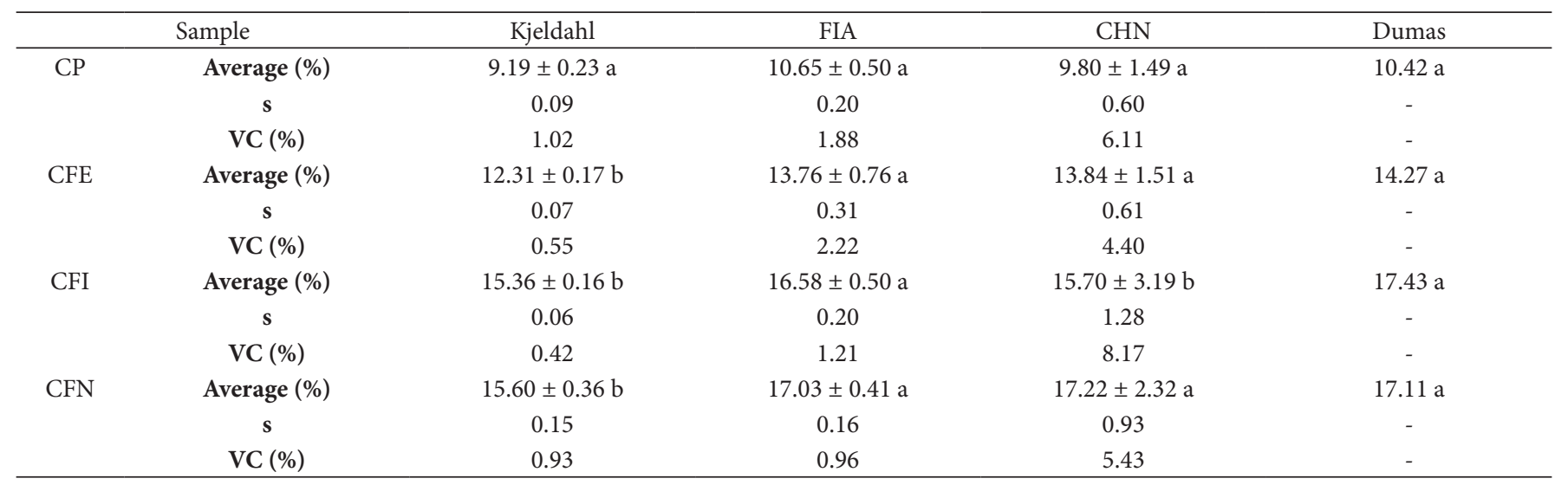


source of variation, as the fewer the mass the more homogeneity is required for it to be representative of the whole.

The temperature used for $\mathrm{CHN}$ analysis was $925^{\circ} \mathrm{C}$ which is under the $1050^{\circ} \mathrm{C}$ required for plants, so the results might be underestimated as some nitrogenous compounds residue may not be decomposed (Smith \& Tabatabai, 2003; Rutherford et al., 2008).

Considering Kjeldahl and the other analyses, the results in general were up to $2 \%$ lower than Dumas for the same sample. Analyzing the Scott-Knott groups, the CFI sample was grouped with the $\mathrm{CHN}$ results and their values were $15.36 \%$ and $15.70 \%$ for Kjeldahl and CHN, respectively.

For CFN and CFE samples, the Kjeldahl methodology had a different result group, lower than others. Only CP sample, reference malting barley, obtained all methods in the same group, though the Kjeldahl result was lower (9.19\%). This is explained by how the nitrogen was presented in this sample.

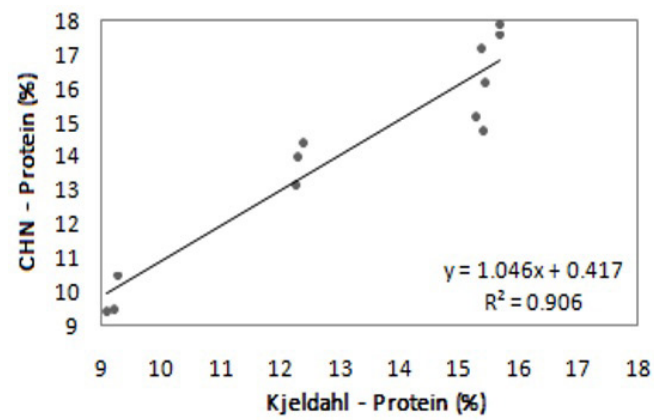

(a)

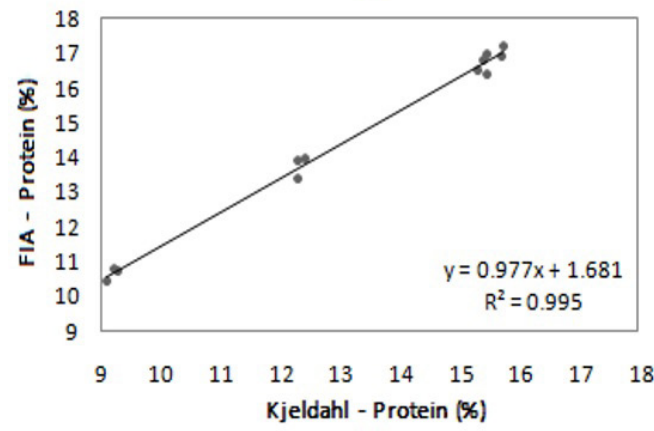

(c)

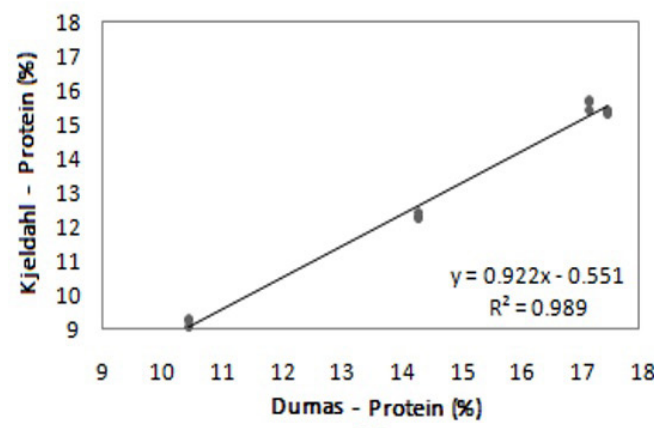

(e)
It is known that Dumas quantifies all nitrogen in the sample, including inorganic sources and organic other than proteins. In combustion, nitrogen is converted into $\mathrm{NO}_{\mathrm{x}}$, then reduced and measured as $\mathrm{N}_{2}$, which overestimates the protein content (Garcia et al., 2015); the same applies to CHN. On the other hand, Kjeldahl does not measure inorganic nitrogen, so its results tend to be lower than combustion ones (Krausová et al., 2018). Therefore, the lower results obtained by digestion methods was caused by the fewer inorganic compounds measured; although they can be quantified if the reduction step is not adequate during digestion, which might be the case for FIA (Jung et al., 2003). Kjeldahl and FIA do not use the same reactants nor have them the same sources of error.

Statistical analysis was done to evaluate the variation between the methods applied and the results are expressed in Table 2. Regression analysis and correlation $\left(\mathrm{R}^{2}\right)$ between values are shown in Figure 1 as a dispersed graph for each two methods as the values varied from $9.19 \%$ to $17.43 \%$.

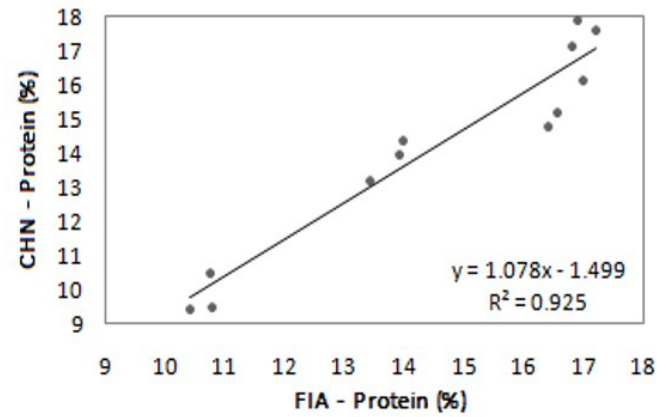

(b)

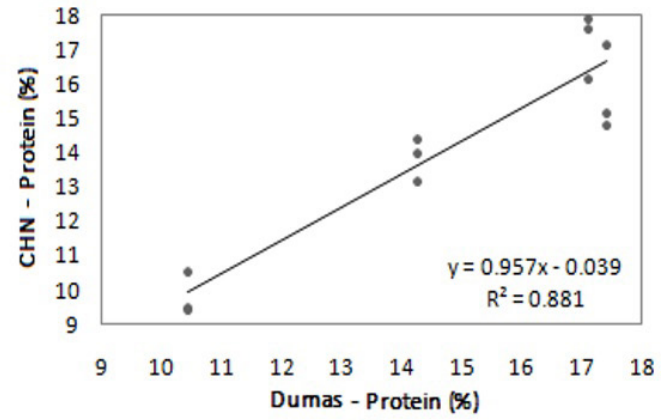

(d)

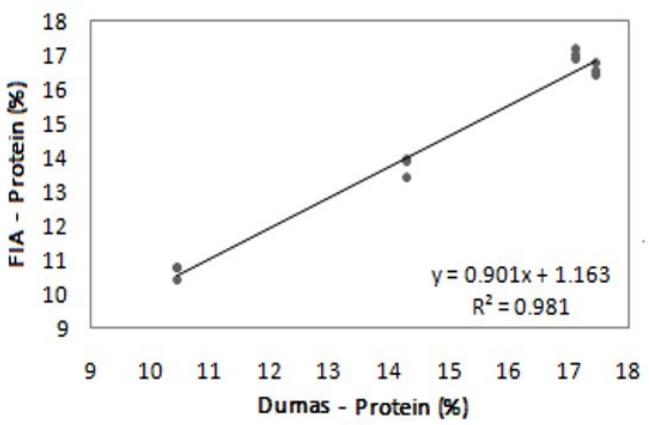

(f)

Figure 1. Regression analysis and correlation between protein content obtained by (a) Kjeldahl and Carbon, Hydrogen and Nitrogen (CHN) elemental analysis, (b) flux injection analysis (FIA) and CHN, (c) Kjeldahl and FIA, (d) Dumas and CHN, (e) Dumas and Kjeldahl and (f) Dumas and FIA. 
Table 2. Comparison between protein quantification methods regarding their overall average, standard deviation ( $\mathrm{s}$ ) and variation coefficient (VC). The samples are CP for BRS Cauê commercial crop cultivated in Southern Brazil; CFE for BRS Cauê in the Federal District; CFI for BRS Brau in the Federal District; and CFN for BRS Brau in State of Goiás, Brazil.

\begin{tabular}{cccc}
\hline Sample & $\begin{array}{c}\text { Methods average } \\
(\%)\end{array}$ & $\mathrm{s}$ & VC (\%) \\
\hline CP & $10.01 \pm 0.82$ & 0.65 & 6.53 \\
CFE & $13.54 \pm 1.04$ & 0.82 & 6.08 \\
CFI & $16.27 \pm 1.27$ & 1.01 & 6.20 \\
CFN & $16.74 \pm 1.01$ & 0.80 & 4.79 \\
\hline
\end{tabular}

There are variations between methodologies due to their characteristics and sample homogeneity, operation modification and specific demands for each method are also sources of error along with random errors. The variation between the methodologies can be explained by the peculiarities of execution of each analysis. Operational changes and the specific requirements of each method promote variation between results, as well as errors associated with them (random errors). Therefore, CFI had the highest divergence between methods, with a standard deviation of 1.01 , mostly because of $\mathrm{CHN}$ results (15.70 with standard deviation (s) of 1.28). Regardless of the method used to quantify protein, $\mathrm{CP}$ was the only one with value under $12 \%$ required by Brazilian law to be used for malting and then brewing.

There is a positive correlation between methods as shown in Figure 1. The highest discrepancy was between CHN and Dumas with $\mathrm{R}^{2}$ of 0.881 and the lowest for FIA and Kjeldahl with 0.995. Saha et al. (2012) obtained a $\mathrm{R}^{2}$ of 0.9985 for dispersion graph between manual and automated Kjeldahl, slightly higher than the one we obtained. Garcia et al. (2015), on the other hand, compared Kjeldahl to Dumas and obtained a $\mathrm{R}^{2}$ of 0.85 lower than the one we obtained, 0.989. Even with the variations presented and the matrix complex the results obtained are satisfactory as their correlations were high and VC were less than $10 \%$, as stated by Pimentel-Gomes (1990) as good VC for agronomic samples. Even with some value dispersions, considering the VC, the experimental data was adequate.

Thus, any methodology can be used to measure protein content as long as specific precautions are taken to minimize errors. It is recommended the use of combustion methods whenever possible due to their advantages. Despite its high operational cost, the operation time is up to six minutes; sample preparation requires only milling and uses no chemical product harmful to humans or to the environment.

\section{Conclusion}

The methodologies tested showed good correlation for $\mathrm{CHN}$ results (higher than 0.881) and excellent for the others (higher than 0.981 ), as variations are related to matrix complexity and systematic errors (sampling and sample preparation). Considering this, all quantification methods for measuring protein content in barley are valid. However, it is recommended the use of combustion methods for their lower production of environment- and health-hazardous residues and the rapid analysis, with results in up to 6 minutes.

\section{Acknowledgements}

The authors acknowledge the Conselho Nacional de Desenvolvimento Científico e Tecnológico (CNPq) and the Coordenação de Aperfeiçoamento de Pessoal de Nível Superior (CAPES) for master scholarships. We also thank the Fundação de Apoio à Pesquisa do Distrito Federal (FAPDF), CNPq and CAPES for financial support. The authors thank farmers and Fundação Agrária de Pesquisa Agropecuária (FAPA) for donating the material used in this study.

\section{References}

Brasil. Ministério da Agricultura, Pecuária e Abastecimento. (1996). Portaria $n^{\circ} 691$ de 22 de Novembro de 1996. Diário Oficial [da] República Federativa do Brasil.

Brennan, C. S., Harris, N., Smith, D., \& Shewry, P. R. (1996). Structural differences in the mature endosperms of good and poor malting barley cultivars. Journal of Cereal Science, 24(2), 171-177. http:// dx.doi.org/10.1006/jcrs.1996.0050.

Briggs, D. E. (1998). Malts and malting. London: Black Academic \& Professional.

Buckee, G. K. (1994). Determination of total nitrogen in barley, malt and beer by Kjeldahl procedures and the Dumas combustion method: collaborative trial. Journal of the Institute of Brewing, 100(2), 57-64. http://dx.doi.org/10.1002/jib.1994.100.2.57.

Chang, S. K. C., \& Zhang, Y. (2017). Protein analysis. In S. S. Nielsen (Ed.), Food analysis (pp. 315-331).Cham, Switzerland: Springer International Publishing. http://dx.doi.org/10.1007/978-3-31945776-5_18.

Cruz, C. D. (2013). GENES: a software package for analysis in experimental statistics and quantitative genetics. Acta Scientiarum. Agronomy, 35(3), 271-276. http://dx.doi.org/10.4025/actasciagron.v35i3.21251.

Dias, M. O., \& Falconi, D. (2018). The evolution of craft beer industry in Brazil. Journal of Economics and Business, 1(4), 618-624. http:// dx.doi.org/10.31014/aior.1992.01.04.55.

Fang, Y., Zhang, X., \& Xue, D. (2019). Genetic analysis and molecular breeding applications of malting quality QTLs in Barley. Frontiers in Genetics, 10(352), 352. http://dx.doi.org/10.3389/fgene.2019.00352. PMid:31068969.

Fox, G. P. (2008). Biochemical and molecular evaluation of quality for malt and feed barley ( $\mathrm{PhD}$ thesis). Southern Cross University, Lismore, Australia.

Garcia, L. F., Carnevalli, R. A., Aragão, L. S., Magalhães, J. C., Pedreira, B. C., \& Giustina, C. D. (2015). Comparação entre dois métodos para determinação de nitrogênio em forragem tropical. In Anais do Congresso Zootecnia (Zootec). Brasília: Associação Brasileira de Zootecnistas.

Jamar, C., Jardin, P. D., \& Fauconnier, M. L. (2011). Cell wall polysaccharides hydrolysis of malting barley (Hordeum vulgare L.): a review. Biotechnologie, Agronomie, Société et Environnement, 15(2), 301-313.

Jung, S., Rickert, D. A., Deak, N. A., Aldin, E. D., Recknor, J., Johnson, L. A., \& Murphy, P. A. (2003). Comparison of kjeldahl and dumas methods for determining protein contents of soybean products. Journal of the American Oil Chemists' Society, 80(12), 1169-1173. http://dx.doi.org/10.1007/s11746-003-0837-3.

Kjeldahl, J. (1883). Neue methode zur bestimmung des stickstoffs in organischen körpern. Zeitschrift für analytische Chemie, 22(1), 366-382. 
Krausová, I., Mizera, J., Dostálek, P., \& Řanda, Z. (2018). Non-destructive determination of nitrogen in malting barleys by instrumental photon activation analysis and its comparison with the Dumas method. Journal of the Institute of Brewing, 124(1), 4-8. http://dx.doi. org/10.1002/jib.477.

Molina-Cano, J. L., Francesch, M., Perez-Vendrell, A. M., Ramo, T., Voltas, J., \& Brufau, J. (1997). Genetic and environmental variation in malting and feed quality of barley. Journal of Cereal Science, 25(1), 37-47. http://dx.doi.org/10.1006/jcrs.1996.0067.

Piacentini, K. C. (2015). Fungos e micotoxinas em grãos de cevada (Hordeum vulgare L.) cervejeira, descontaminação pelo gás ozônio e segurança de cervejas artesanais (Dissertação de mestrado). Universidade Federal de Santa Catarina, Florianópolis.

Pimentel-Gomes, F. (1990). Curso de estatística experimental (13. ed.). Piracicaba: Nobel.

Psota, V., Vejražka, K., Faměra, O., \& Hrčka, M. (2007). Relationship between grain hardness and malting quality of barley (Hordeum vulgare L.). Journal of the Institute of Brewing, 113(1), 80-86. http:// dx.doi.org/10.1002/j.2050-0416.2007.tb00260.x.

Rutherford, P., McGill, W. B., Arocena, J. M., \& Figueiredo, C. T. (2008). Total nitrogen. In M. R. Carter, \& E. G. Gregorich (Eds.), Soil sampling and methods of analysis (pp. 239-250). Boca Raton: CRC Press.

Sá, R. M., \& Palmer, G. H. (2004). Assessment of enzymatic endosperm modification of malting barley using individual grain analyses. Journal of the Institute of Brewing, 110(1), 43-50. http://dx.doi. org/10.1002/j.2050-0416.2004.tb00179.x.

Sáez-Plaza, P., Michalowski, T., Navas, M. J., Asuero, A. G., \& Wybraniec, S. (2013a). An overview of the kjeldahl method of nitrogen determination. Part I. Early history, chemistry of the procedure, and titrimetric finish. Critical Reviews in Analytical Chemistry, 43(4), 178-223. http://dx.doi.org/10.1080/10408347.2012.751786.

Sáez-Plaza, P., Navas, M. J., Wybraniec, S., Michalowski, T., \& Asuero, A. G. (2013b). An overview of the kjeldahl method of nitrogen determination. Part II. Sample preparation, working scale, instrumental finish, and quality control. Critical Reviews in Analytical Chemistry, 43(4), 224-272. http://dx.doi.org/10.1080/10408347.2012.751787.

Saha, U. K., Sonon, L., \& Kissel, D. E. (2012). Comparison of conductimetric and colorimetric methods with distillation-titration method of analyzing ammonium nitrogen in total kjeldahl digests. Communications in Soil Science and Plant Analysis, 43(18), 23232341. http://dx.doi.org/10.1080/00103624.2012.708081.

Scobie, M. N., \& Jones, M. G. K. (2010). Identification of barley varieties by protein profiling. In G. Zhang \& C. Li (Eds.), Genetics and improvement of barley malt quality (Chap. 4, pp. 99-112). Heidelberg, Germany: Springer.

Smith, K. A., \& Tabatabai, M. A. (2003). Automated instruments for the determination of total carbon, hydrogen, nitrogen, sulfur, and oxygen. In K. A. Smith, \& M. S. Cresser (Eds.), Soil and environmental analysis: modern instrumental techniques (Chap. 6. pp. 235-282). Boca Raton: CRC Press. http://dx.doi.org/10.1201/9780203913024.

Watson, M. E., \& Galliher, T. L. (2001). Comparison of Dumas and Kjeldahl methods with automatic analyzers on agricultural samples under routine rapid analysis conditions. Communications in Soil Science and Plant Analysis, 32(13-14), 2007-2019. http://dx.doi. org/10.1081/CSS-120000265.

Zhang, G., Chen, J., Wang, J., \& Ding, S. (2001). Cultivar and environmental effects on $(1 \rightarrow 3,1 \rightarrow 4)-\beta$-D-glucan and protein content in malting barley. Journal of Cereal Science, 34(3), 295-301. http://dx.doi. org/10.1006/jcrs.2001.0414. 